Article

\title{
The Influence of Vegetation Succession on Bearing Capacity of Forest Roads Made of Unbound Aggregates
}

\author{
Sylwester M. Grajewski ${ }^{\infty}$, Andrzej Czerniak ${ }^{(D)}$ and Ewa E. Kurowska *(D) \\ Department of Forest Engineering, Faculty of Forestry and Wood Technology, Poznań University of Life Sciences, \\ 60-623 Poznań, Poland; sylwester.grajewski@up.poznan.pl (S.M.G.); andrzej.czerniak@up.poznan.pl (A.C.) \\ * Correspondence: ewa.kurowska@up.poznan.pl
}

Received: 22 September 2020; Accepted: 24 October 2020; Published: 27 October 2020

check for updates

\begin{abstract}
The aim of the research was to verify a common opinion concerning a positive influence of plants on the bearing capacity and durability of forest roads made of unbound aggregates. The surface bearing capacity is defined as the ability to transfer traffic loads without any excessive deformations which would hinder regular use of the surface and shorten its durability. It is a significant functional feature of any road. The article analyzed the influence of road surface plant succession on its bearing parameters. The research was conducted on sections of experimental road constructed using macadam technology and reinforced partly with a biaxial geogrid. Measurements were taken with a lightweight Zorn ZFG 3000 GPS type deflectometer with a $300 \mathrm{~mm}$ pressure plate radius and $10 \mathrm{~kg}$ drop weight which allowed to measure dynamic deformation modulus $\left(E_{\mathrm{vd}}\right)$ and $\mathrm{s} / \mathrm{v}$ parameter regarded as an indicator of compaction accuracy of the studied layer. $\mathrm{E}_{\mathrm{vd}}$ values and $\mathrm{s} / \mathrm{v}$ parameters, which were obtained by measuring the road pavement covered in vegetation and after having it mechanically removed (mowed), were submitted to the analysis; next, they were compared with the results of an analysis done on areas naturally deprived of the plant cover and located in the immediate vicinity of the measuring points. The conducted research has indicated unfavorable influence of vegetation succession on the bearing parameters of the analyzed sections. The greatest drop in the mean $\mathrm{E}_{\mathrm{vd}}$ value was $39 \%$, and s/v parameter deteriorated as much as $9 \%$. Hence, a regular mowing of the road surface (including the maneuvering, storage and passing areas) should be taken as standard and mandatory procedures of forest road maintenance.
\end{abstract}

Keywords: roads maintenance; bearing capacity; plant succession; surface degradation; lightweight deflectometer

\section{Introduction}

Currently in Poland, in the forest road construction process, the roads are usually built from natural aggregate, whereas recycled materials reinforced with geosynthetics are used less often [1].

In the past, plant materials were used in road construction, especially on wetlands, such as for example, wooden poles, fascine or brushwood were used to lay the base course [2-4]. In Poland, a study on such a technology is conducted aimed at use of wooden rollers poles) or willow mat to reinforce the road courses constructed in high nature-value wetlands [5,6]. Among the technologies that use plant materials applied in the other parts of the world positive results are achieved by reinforcing the ground of the road course with coconut fibres i.e., [7-11]. Moreover, at times, during fieldwork it is possible to observe, makeshift methods of improving the bearing capacity of natural dirt road by using bark or woodchips or other methods of dirt road, and even airfield reinforcing such as sodding [12].

Roadside vegetation performs a very important protective function against soil erosion $[13,14]$. It protects the cut slopes and fill slopes, prevents fine material outwashing and sediment 
production[15-22], then its transport and adverse deposition [23], thus prevents weakening of all the road, shoulder and side slope surfaces. Stabilization by vegetation within a wider spatial range contributes to the protection of watercourses, water bodies and forest catchment areas [24]; finally plants counteract mass movements in mountainous regions [25-28].

The protective vegetation cover of the slope is usually introduced artificially. However, the portion of land bared during construction works on a forest road may also be submitted to a strong natural plant succession. The processes which occur in the roadside zone should be regarded as beneficial, particularly in single-species tree stands, provided that the species spread by means of transport and anemochory, are not invasive. Low vegetation (grasses, mosses) growing on natural dirt roads, which are particularly erosive, has ability to improve road stability $[13,14,19]$. Other studies indicate that root systems, especially of some particular species of trees and shrubs, can damage roads due to physical forces exerted by root's growth $[29,30]$. The root system size depends on the tree species, humidity and soil fertility [31-33].

Research show that, on the road surface made of aggregates, conditions conducive to the growth of undesirable vegetation on the road surface are created as a result of accumulation and decomposition of organic matter. Organic material can contribute to destruction of the road, retaining moisture and creating a less adhesive surface [34]. Therefore, the unwanted vegetation should be removed, preferably mechanically with special rotary brushes [35]. In Poland, principles of removing organic pollutants from the forest roads have been developed and published in form of technical manual [36], what is more, a special device for removing vegetation from the road was invented. The device is combined with a tractor and its operation is based on herbicide lubrication of vegetation on the roadway and the roadside [36].

In this paper an attempt was made to determine whether the appearing vegetation has also a beneficial influence on the bearing capacity of the pavement made of unbound aggregate. The pavement bearing capacity is defined as the ability to transfer traffic loads without producing any excessive deformations which would hinder regular use of the surface and shorten its durability; it is a significant functional feature of any road [37]. The bearing capacity is determined by entire road structure, i.e., the number and thickness of layers (wearing course, base course and subbase course), the type and quality of the materials used, as well as the quality of roadwork and the condition of the soil subgrade. As mentioned above, many positive aspects of the influence of plant cover on road and roadside zone are widely known and described, however, the aspect related to road surface bearing capacity has not yet been recognized by other researchers. In this article we present the results of research on this particular issue.

\section{Materials and Methods}

The research presented in this paper focused on analyzing the influence of vegetation succession on the road pavement made of unbound aggregates, and /more precisely/ on its bearing capacity. The bearing capacity tests were conducted three times (June 2019, May 2020 and September 2020) on the two selected experimental used for constructing the road was crushed stone technology reinforced with road sections which had been set up in autumn 2016 in Gryfino Forest District (Regional Directorate of State Forests in Szczecin). The technology a biaxial geogrid (Figures 1 and 2, Table 1). The tests were done on the passing and storage places with an initiated intensive process of plant succession. The vegetation presence on the road surface reflects the low use of the road. 


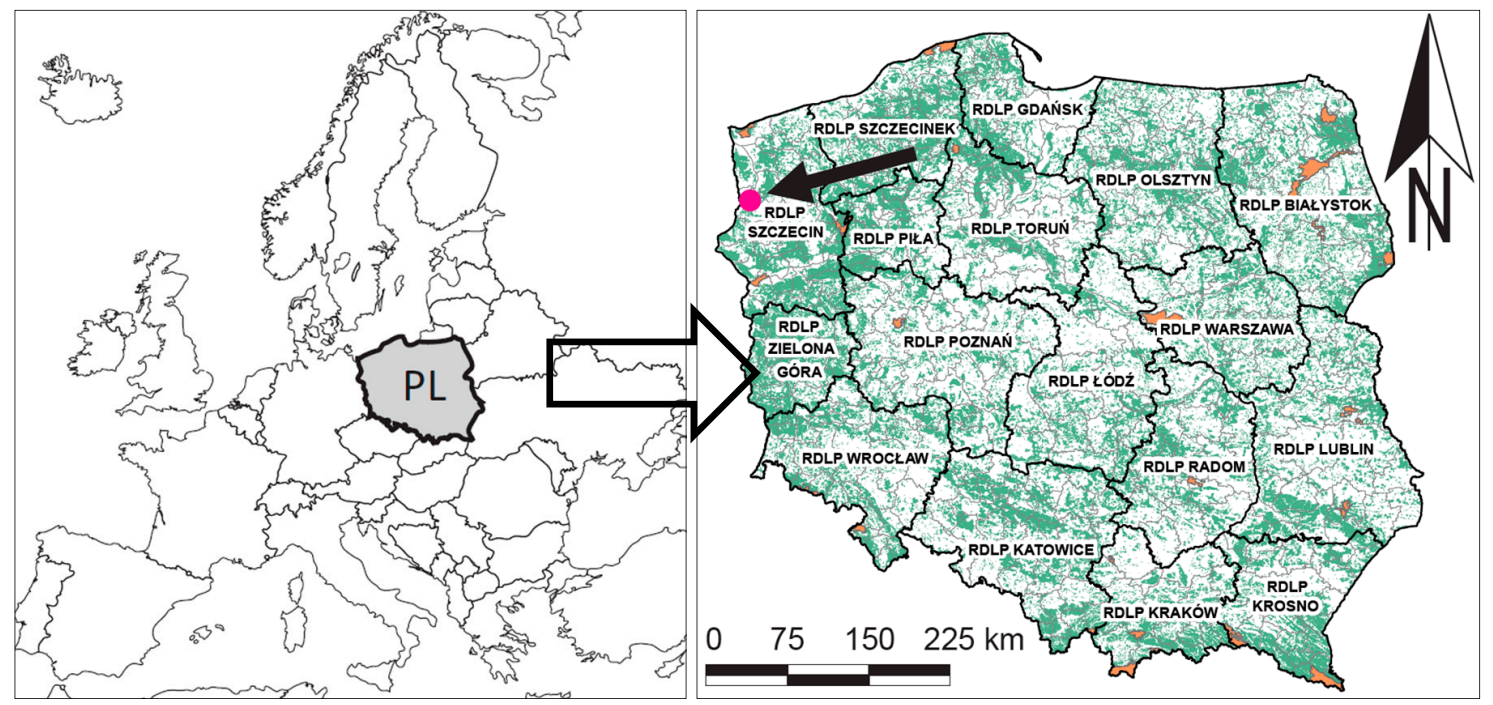

Figure 1. Location of the research area on the map of Poland with division into Regional Directorates of State Forests (RDLP).

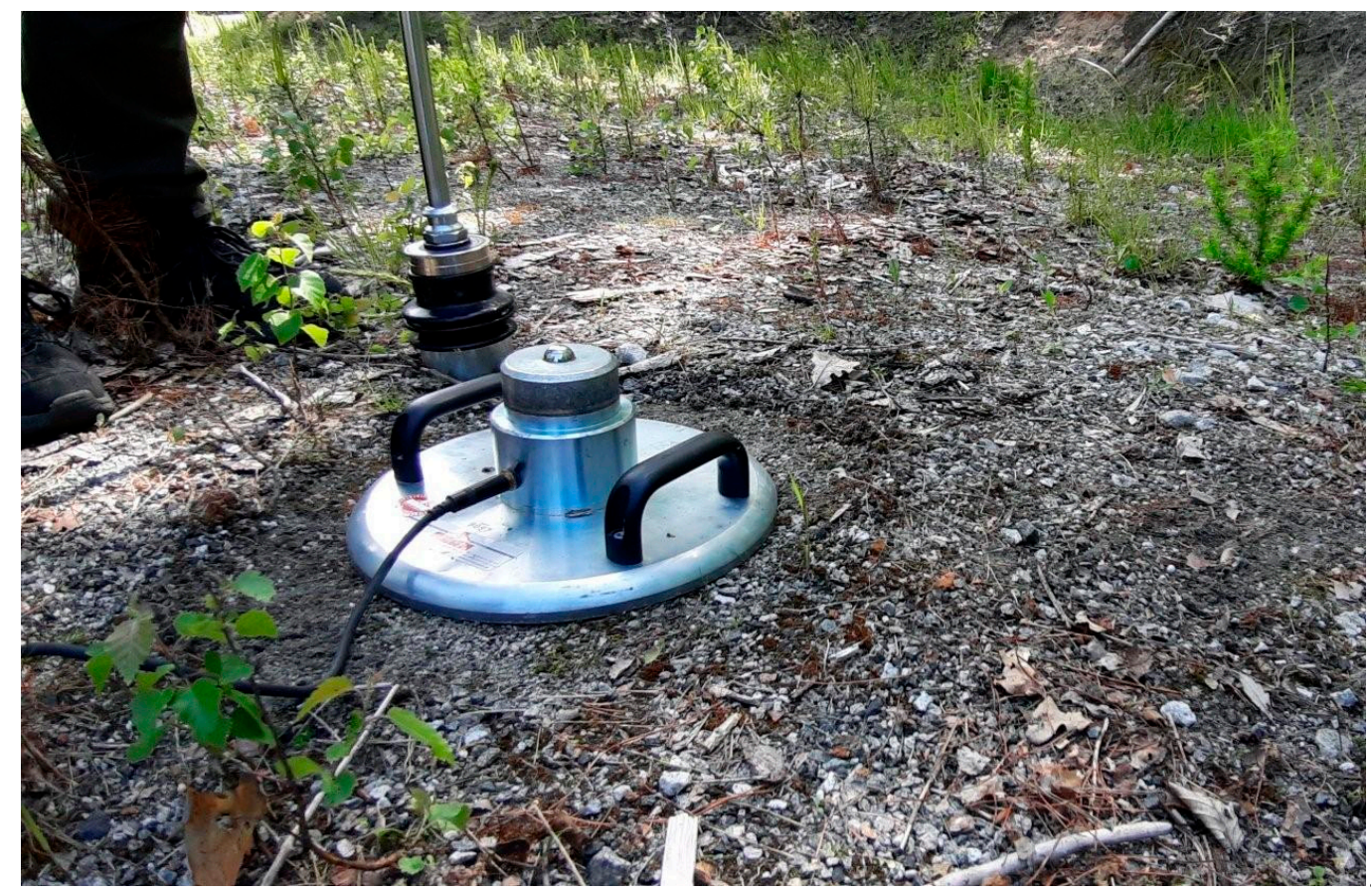

Figure 2. The bearing capacity testing with lightweight deflectometer on the experimental forest road section no. 2 in spring 2020, in the place where vegetation had been previously removed- " $E$ " symbol in Table 2 (Photo: S. M. Grajewski).

The bearing capacity was measured with a lightweight ZFG 3000 GPS type deflectometer (Zorn Instruments $\mathrm{GmbH} \& \mathrm{Co}$. KG, Hansestadt Stendal, Germany) with a $300 \mathrm{~mm}$ radius pressure plate and a $10 \mathrm{~kg}$ drop weight. The instrument was used to measure dynamic deformation modulus $\left(\mathrm{E}_{\mathrm{vd}}\right)$ and $\mathrm{s} / \mathrm{v}$ parameter (ratio of mean load settlement (deflection) after three impact LFWD tests to mean settlement velocity (deflection rate)), which is an indicator of compaction accuracy of the studied layer [38]. The $E_{v d}$ values and $s / v$ parameter obtained during the tests on the road pavement covered with vegetation and after its mechanical removal were later compared with the results of the tests conducted in the direct vicinity, where the area was naturally devoid of vegetation cover (reference points). 
Table 1. Description of the studied experimental road sections.

\begin{tabular}{|c|c|c|}
\hline Road Section Number & Element & Description \\
\hline \multirow{5}{*}{1} & $\begin{array}{l}\text { Pavement, shoulder, passing place } \\
\text { and storage area }\end{array}$ & $\begin{array}{c}\text { The width of the road with a left-side crossfall } 4 \%-3.5 \mathrm{~m} \text {; the } \\
\text { width of shoulders reinforced with natural aggregate and } \\
\text { crossfall } 6 \%-2 \times 0.75 \mathrm{~m} \text {; passing places } 3.0 \mathrm{~m} \text { wide and } 23.0 \mathrm{~m} \\
\text { long with slants in } 1: 7 \text { ratio; storage area } 10.0 \mathrm{~m} \text { wide and } \\
40.0 \mathrm{~m} \text { long. }\end{array}$ \\
\hline & Wearing course & $\begin{array}{c}0-12 \mathrm{~cm} \text { mechanically stabilised crushed stone aggregate } \\
0 / 31.5 \mathrm{~mm} \text { with stony silt coating } 0 / 8 \mathrm{~mm} .\end{array}$ \\
\hline & Base course & $\begin{array}{l}12-27 \mathrm{~cm} \text { mechanically stabilised crushed stone aggregate } \\
0 / 63 \mathrm{~mm} .\end{array}$ \\
\hline & Subbase course (frost resistant layer) & $\begin{array}{l}\text { 27-42 } \mathrm{cm} \text { mechanically stabilised natural fine } \\
\text { aggregate—-medium sand (MSa). }\end{array}$ \\
\hline & Soil subgrade & 43-250 cm sandy clay $(\mathrm{saCl})$. \\
\hline \multirow{5}{*}{2} & Pavement, shoulder, storage area & $\begin{array}{l}\text { The width of the road with two-way crossfall } 4 \%-3.5 \mathrm{~m} \text {; the } \\
\text { width of shoulders reinforced with natural aggregate with } \\
\text { crossfall } 6 \%-2 \times 0.5 \mathrm{~m} \text {; storage area } 10.0 \mathrm{~m} \text { wide and } \\
40.0 \mathrm{~m} \text { long. }\end{array}$ \\
\hline & Wearing course & $\begin{array}{c}0-12 \mathrm{~cm} \text { mechanically stabilised crushed stone aggregate } \\
0 / 31.5 \mathrm{~mm} \text { with stony silt coating } 0 / 8 \mathrm{~mm} .\end{array}$ \\
\hline & Base course & $\begin{array}{l}12-27 \mathrm{~cm} \text { mechanically stabilised crushed stone aggregate } \\
\text { 0/63mm. } \\
\begin{array}{l}\text { Biaxial geogrid (MD/CMD acc. [39] 33/33 (-3) } \mathrm{kN} / \mathrm{m} \text { ) with } 30 \\
\times 30 \mathrm{~mm} \text { aperture. }\end{array}\end{array}$ \\
\hline & Subbase course (frost resistant layer) & $\begin{array}{l}27-42 \mathrm{~cm} \text { mechanically stabilised natural fine } \\
\text { aggregate-medium sand (MSa). }\end{array}$ \\
\hline & Soil subgrade & $\begin{array}{l}\text { 42-250 cm fine sand (FSa) intercalated with clayey sand } \\
\text { (FSaclSa). }\end{array}$ \\
\hline
\end{tabular}

The vegetation covering the experimental road sections was at most $0.5 \mathrm{~m}$ high. In the process of data analyzing, the type of road pavement (on the section no. 1 and section no. 2) and the preparation manner of the measurement sites were taken into account as well (Table 2).

Table 2. The analyzed data sets and adopted coding system.

\begin{tabular}{|c|c|c|c|}
\hline Section No. & Testing Season & The Data Set Specification & Assigned Data Set Symbol * \\
\hline 1 & Spring 2019 & $\begin{array}{l}\text { The results of bearing capacity } \\
\text { measurements taken in the places } \\
\text { covered with vegetation }\end{array}$ & A \\
\hline 1 & Spring 2019 & $\begin{array}{l}\text { The results of bearing capacity } \\
\text { measurements taken in the places } \\
\text { deprived of vegetation, located in the } \\
\text { direct vicinity of spots from set " } \mathrm{A}^{\text {" }} \\
\text { sites (reference point) }\end{array}$ & B \\
\hline 2 & Spring 2019 & $\begin{array}{c}\text { The results of bearing capacity } \\
\text { measurements taken in the places } \\
\text { covered with vegetation }\end{array}$ & $\mathrm{C}$ \\
\hline 2 & Spring 2019 & $\begin{array}{l}\text { The results of bearing capacity } \\
\text { measurements taken in the places } \\
\text { deprived of vegetation, located in the } \\
\text { direct vicinity of spots from set "C" sites } \\
\text { (reference point) }\end{array}$ & $\mathrm{D}$ \\
\hline 1 & Spring 2020 & No results due to a technical problem & - \\
\hline 1 & Spring 2020 & No results due to a technical problem & - \\
\hline
\end{tabular}


Table 2. Cont.

\begin{tabular}{|c|c|c|c|}
\hline Section No. & Testing Season & The Data Set Specification & Assigned Data Set Symbol * \\
\hline 2 & Spring 2020 & $\begin{array}{l}\text { The results of bearing capacity } \\
\text { measurements taken in the places with } \\
\text { vegetation after its mechanical } \\
\text { eradication (mowing to the level of the } \\
\text { road pavement) }\end{array}$ & $\mathrm{E}$ \\
\hline 2 & Spring 2020 & $\begin{array}{l}\text { The results of bearing capacity } \\
\text { measurements taken in the sites } \\
\text { deprived of vegetation in the direct } \\
\text { vicinity of spots from set "E" } \\
\text { (reference point) }\end{array}$ & $\mathrm{F}$ \\
\hline 1 & Autumn 2020 & $\begin{array}{l}\text { Results of bearing capacity } \\
\text { measurements taken in the places with } \\
\text { vegetation after its mechanical } \\
\text { eradication (mowing to the level of the } \\
\text { road pavement) }\end{array}$ & G \\
\hline 1 & Autumn 2020 & $\begin{array}{l}\text { The results of bearing capacity } \\
\text { measurements taken in the sites } \\
\text { deprived of vegetation in the direct } \\
\text { vicinity of spots from set "G" }\end{array}$ & $\mathrm{H}$ \\
\hline 2 & Autumn 2020 & $\begin{array}{l}\text { The results of bearing capacity } \\
\text { measurements taken in the places with } \\
\text { vegetation after its mechanical } \\
\text { eradication (mowing to the level of the } \\
\text { road pavement) }\end{array}$ & I \\
\hline 2 & Autumn 2020 & $\begin{array}{l}\text { The results of bearing capacity } \\
\text { measurements taken in sites deprived } \\
\text { of vegetation in the direct vicinity of } \\
\text { spots from set "I" }\end{array}$ & $\mathrm{J}$ \\
\hline
\end{tabular}

The plant species which occurred in the study area were catalogued in detail, determining the species structure and surface coverage. The degree of coverage was determined by geodesic methods on randomly selected sections of the road surface. The species structure was recognized by analyzing the species within randomly selected square segments with sides of $100 \mathrm{~cm}$. The plant inventory made it possible to select the bearing capacity test sites where vegetation coverage reached $80-90 \%$.

For statistical evaluation of differences between groups of variables, the Tukey test for different $\mathrm{N}^{\prime}$ s, available in Statistica ${ }^{\mathrm{TM}} 13$ (TIBCO ${ }^{\circledR}$ Software Inc., Palo Alto, CA, USA), was used.

\section{Results}

During the spring 2019 and 2020 field work, in the study area, in total 10 vegetation taxa aged 1-3 years were catalogued (Table 3 ). The vegetation coverage was about $80 \%$. The species structure was by far dominated by a young generation of silver birch (Betula pendula Roth) and Scots pine (Pinus sylvestris L.), which covered the greatest part of the research area. In autumn 2020, a total of 34 plant species aged 1-4 years were identified, with 30 taxa on the road section no. 1, and 16 taxa on the section no. 2 (Table 3). The degree of road surface coverage increased to about $90 \%$. 
Table 3. The vegetation inventory on bearing capacity research area - experimental sections (passing area and storage area).

\begin{tabular}{|c|c|c|c|c|c|}
\hline $\begin{array}{l}\text { Road Section } \\
\text { Number (Sn) }\end{array}$ & Testing Season & Data Set Symbol & Type of Testing Place & Plant Species & $\begin{array}{l}\text { Species Structure (Percentage Share } \\
\text { in the Study Segment) }\end{array}$ \\
\hline \multirow{31}{*}{1} & \multirow{11}{*}{$\begin{array}{l}\text { Spring } 2019 \text { and } \\
\text { spring } 2020\end{array}$} & \multirow{5}{*}{ A, B } & \multirow{5}{*}{ Passing place } & $\begin{array}{l}\text { black locust Robinia pseudoacacia } \mathrm{L} \text {. } \\
\text { common aspen Populus tremula L. and grey poplar Populus canescens } \\
\text { eared willow Salix aurita L. }\end{array}$ & $\begin{array}{l}\text { single } \\
\text { single } \\
\text { single }\end{array}$ \\
\hline & & & & Scots pine Pinus sylvestris L. & $20 \%$ \\
\hline & & & & silver birch Betula pendula Roth & $40 \%$ \\
\hline & & & & wood small-reed Calamagrostis epigejos (L.) Roth. & $20 \%$ \\
\hline & & & & Road surface coverage degree & $80 \%$ \\
\hline & & \multirow{6}{*}{$\mathrm{A}, \mathrm{B}$} & \multirow{6}{*}{ Storage area } & common aspen Populus tremula L. and grey poplar Populus canescens & single \\
\hline & & & & Scots pine Pinus sylvestris L. & $10 \%$ \\
\hline & & & & silver birch Betula pendula Roth & $50 \%$ \\
\hline & & & & white clover Trifolium repens $\mathrm{L}$. & single \\
\hline & & & & wood small-reed Calamagrostis epigejos (L.) Roth & $20 \%$ \\
\hline & & & & Road surface coverage degree & $80 \%$ \\
\hline & \multirow{20}{*}{ Autumn 2020} & \multirow{20}{*}{$\mathrm{G}, \mathrm{H}$} & \multirow{20}{*}{ Storage area } & annual meadow grass Роа аппиа L. & single \\
\hline & & & & black locust Robinia pseudoacacia L. & single \\
\hline & & & & broadleaf plantain Plantago major $\mathrm{L}$. & single \\
\hline & & & & Canadian hawkweed Hieracium umbellatum $\mathrm{L}$. & single \\
\hline & & & & chamomile Matricaria chamomilla $\mathrm{L}$. & single \\
\hline & & & & charlock mustard Sinapis arvensis L. & single \\
\hline & & & & coltsfoot Tussilago farfara $\mathrm{L}$. & single \\
\hline & & & & common aspen Populus tremula L. and grey poplar Populus canescens & single \\
\hline & & & & $\begin{array}{l}\text { common hemp-nettle Galeopsis tetrahit } \mathrm{L} \text {. } \\
\text { common knotgrass Polygonum aviculare } \mathrm{L} \text {. }\end{array}$ & $\begin{array}{l}\text { single } \\
\text { single }\end{array}$ \\
\hline & & & & common mugwort Artemisia vulgaris L. & single \\
\hline & & & & common tansy Tanacetum vulgare $\mathrm{L}$. & single \\
\hline & & & & $\begin{array}{l}\text { creeping thistle Cirsium arvense (L.) Scop } \\
\text { dandelion Taraxacum officinale (L.) Weber ex F.H. Wigg }\end{array}$ & $\begin{array}{l}\text { single } \\
\text { sincle }\end{array}$ \\
\hline & & & & $\begin{array}{l}\text { denseflower mullein Verbascum densiflorum Bertol. } \\
\text { do }\end{array}$ & single \\
\hline & & & & eared willow Salix aurita L. & single \\
\hline & & & & European black nightshade Solanum nigrum $\mathrm{L}$. & single \\
\hline & & & & European goldenrod Solidago virgaurea $\mathrm{L}$. & single \\
\hline & & & & field pansy Viola arvensis Murr. & single \\
\hline & & & & gallant soldier Galinsoga parviflora Cav. & single \\
\hline & & & & goat willow Salix caprea $\mathrm{L}$. & single \\
\hline & & & & green amaranth Amaranthus hybridus $\mathrm{L}$. & single \\
\hline
\end{tabular}


Table 3. Cont.

\begin{tabular}{|c|c|c|c|c|c|}
\hline $\begin{array}{l}\text { Road Section } \\
\text { Number (Sn) }\end{array}$ & Testing Season & Data Set Symbol & Type of Testing Place & Plant Species & $\begin{array}{l}\text { Species Structure (Percentage Share } \\
\text { in the Study Segment) }\end{array}$ \\
\hline \multirow[t]{2}{*}{1} & \multirow[t]{2}{*}{ Autumn 2020} & \multirow[t]{2}{*}{$\mathrm{G}, \mathrm{H}$} & \multirow[t]{2}{*}{ Storage area } & $\begin{array}{l}\text { horseweed Erigeron canadensis (L.) Cronquist } \\
\text { lamb's quarters Chenopodium album } \mathrm{L} \text {. } \\
\text { ribwort plantain Plantago lanceolata } \mathrm{L} \text {. } \\
\text { Scots pine Pinus sylvestris L. } \\
\text { silver birch Betula pendula Roth } \\
\text { small balsam Impatiens parviflora DC. } \\
\text { white clover Trifolium repens } \mathrm{L} \text {. } \\
\text { wood small-reed Calamagrostis epigejos (L.) Roth }\end{array}$ & $\begin{array}{c}10 \% \\
\text { single } \\
\text { single } \\
10 \% \\
50 \% \\
\text { single } \\
\text { single } \\
20 \%\end{array}$ \\
\hline & & & & Road surface coverage degree & $90 \%$ \\
\hline \multirow{4}{*}{2} & \multirow[t]{2}{*}{$\begin{array}{l}\text { Spring } 2019 \text { and } \\
\text { spring } 2020\end{array}$} & \multirow[t]{2}{*}{$\mathrm{C}, \mathrm{D}, \mathrm{E}, \mathrm{F}$} & \multirow[t]{2}{*}{ Storage area } & $\begin{array}{l}\text { common aspen Populus tremula } \mathrm{L} \text {. and grey poplar Populus canescens } \\
\text { eared willow Salix aurita } \mathrm{L} \text {. } \\
\text { European larch Larix decidua Mill. } \\
\text { large-leaved lupine Lupinus polyphyllus } \mathrm{L} \text {. } \\
\text { Scots pine Pinus sylvestris } \mathrm{L} \text {. } \\
\text { silver birch Betula pendula Roth } \\
\text { viper's bugloss Echium vulgare } \mathrm{L} \text {. } \\
\text { white clover Trifolium repens } \mathrm{L} \text {. } \\
\text { wood small-reed Calamagrostis epigejos (L.) Roth }\end{array}$ & $\begin{array}{c}\text { single } \\
\text { single } \\
\text { single } \\
\text { single } \\
10 \% \\
50 \% \\
\text { single } \\
\text { single } \\
20 \%\end{array}$ \\
\hline & & & & Road surface coverage degree & $80 \%$ \\
\hline & \multirow[t]{2}{*}{ Autumn 2020} & \multirow[t]{2}{*}{$\mathrm{I}, \mathrm{J}$} & & $\begin{array}{l}\text { annual meadow grass Poa annua } \mathrm{L} \text {. } \\
\text { broadleaf plantain Plantago major } \mathrm{L} \text {. } \\
\text { Canadian hawkweed Hieracium umbellatum } \mathrm{L} \text {. } \\
\text { coltsfoot Tussilago farfara } \mathrm{L} \text {. } \\
\text { common aspen Populus tremula } \mathrm{L} \text {. and grey poplar Populus canescens } \\
\text { common bent Agrostis capillaris } \mathrm{L} \text {. } \\
\text { dandelion Taraxacum officinale } \text { (L.) Weber ex F.H. Wigg } \\
\text { eared willow Salix aurita } \mathrm{L} \text {. } \\
\text { European larch Larix decidua Mill. } \\
\text { goat willow Salix caprea } \mathrm{L} \text {. } \\
\text { hare's-foot clover Trifolium arvense } \mathrm{L} \text {. } \\
\text { horseweed Erigeron canadensis (L.) Cronquist } \\
\text { Scots pine Pinus sylvestris } \mathrm{L} \text {. } \\
\text { silver birch Betula pendula Roth } \\
\text { wood small-reed Calamagrostis epigejos }(\mathrm{L} .) \text { Roth } \\
\text { wormwood Artemisia absinthium } \mathrm{L} \text {. }\end{array}$ & $\begin{array}{l}\text { single } \\
\text { single } \\
\text { single } \\
\text { single } \\
\text { single } \\
\text { single } \\
\text { single } \\
\text { single } \\
\text { single } \\
\text { single } \\
\text { single } \\
\text { single } \\
10 \% \\
60 \% \\
20 \% \\
\text { single }\end{array}$ \\
\hline & & & & Road surface coverage degree & $90 \%$ \\
\hline
\end{tabular}


On average, the highest values of dynamic deformation modulus were observed for the measurements taken on road section no. 1 ( 58.58 and $50.9 \mathrm{MN} \cdot \mathrm{m}^{-2}$ ) and a bit lower on road section no. 2 $\left(47.04 \mathrm{MN} \cdot \mathrm{m}^{-2}, 44.16\right.$ and $\left.38.21 \mathrm{MN} \cdot \mathrm{m}^{-2}\right)$ in all the testing sites not covered with vegetation succession (marked with letter-symbols B, H, D, F and J; see Table 4 and Figure 3). The differences shown were confirmed statistically with the exception of $C$ and D data sets relations (Table 4). The presence of vegetation on the road pavement, regardless of the manner the measurement was taken, resulted in lowering the $\mathrm{E}_{\mathrm{vd}}$ value by $18 \%$ (in cases I-J), and sometimes even by $39 \%$ (in cases B-A). There is also a noticeable 13\% (D-J), 17\% (B-H) and 19\% (F-J) decrease in the value of the dynamic modulus of deformation in the third testing season, comparing to the previous test results. The road pavement of section no. 1 (without the biaxial geogrid), despite displaying initially higher bearing capacity (B), responded with significantly lowered values of the dynamic deformation modulus values once the vegetation appeared $(\mathrm{A})$.

Table 4. The results of testing the bearing capacity with light weight deflectometer on the experimental road sections.

\begin{tabular}{|c|c|c|c|c|c|c|c|c|c|c|c|c|c|}
\hline \multirow{2}{*}{ DSS } & \multirow{2}{*}{$\mathbf{N}$} & \multicolumn{6}{|c|}{$\mathrm{E}_{\mathrm{vd}}\left[\mathrm{MN} \cdot \mathrm{m}^{-2}\right]$} & \multicolumn{6}{|c|}{$\mathrm{s} / \mathrm{v}[\mathrm{ms}]$} \\
\hline & & $\overline{\mathbf{x}}^{*}$ & $x_{\min }$ & $x_{\max }$ & SD & $\mathrm{S}_{\mathrm{e}}$ & $z_{p}[\%]$ & $\overline{\mathbf{x}}^{*}$ & $x_{\min }$ & $x_{\max }$ & SD & $\mathrm{S}_{\mathrm{e}}$ & $z_{p}[\%]$ \\
\hline 1 & 2 & 3 & 4 & 5 & 6 & 7 & 8 & 9 & 10 & 11 & 12 & 13 & 14 \\
\hline A & 11 & $35.80 \mathrm{abc}$ & 16.27 & 50.33 & 12.42 & 2.53 & 35 & $2.665 \mathrm{abc}$ & 2.344 & 3.311 & 0.316 & 0.073 & 12 \\
\hline B & 11 & $58.58^{\mathrm{e}}$ & 47.07 & 72.97 & 8.79 & 2.53 & 15 & $2.489 \mathrm{ad}$ & 2.192 & 2.828 & 0.204 & 0.073 & 8 \\
\hline C & 10 & $32.56^{\mathrm{ab}}$ & 15.73 & 49.12 & 13.28 & 2.65 & 41 & $2.948^{c}$ & 2.366 & 4.130 & 0.510 & 0.077 & 17 \\
\hline $\mathrm{D}$ & 10 & $44.16^{\mathrm{bcd}}$ & 26.74 & 60.00 & 9.68 & 2.65 & 22 & $2.712 \mathrm{abc}$ & 2.345 & 3.089 & 0.244 & 0.077 & 9 \\
\hline E & 20 & $38.03^{\mathrm{ab}}$ & 28.70 & 47.67 & 5.33 & 1.88 & 14 & $2.740^{a b c}$ & 2.545 & 3.006 & 0.139 & 0.054 & 5 \\
\hline F & 20 & $47.04^{\mathrm{cd}}$ & 38.46 & 57.99 & 5.84 & 1.88 & 12 & $2.655^{\mathrm{abc}}$ & 2.367 & 2.937 & 0.196 & 0.054 & 7 \\
\hline G & 20 & $36.81^{\mathrm{ab}}$ & 16.90 & 54.22 & 10.05 & 1.68 & 27 & $2.541^{\mathrm{ab}}$ & 2.185 & 3.428 & 0.292 & 0.049 & 11 \\
\hline $\mathrm{H}$ & 20 & 50.09 de & 26.66 & 65.98 & 7.52 & 1.68 & 15 & $2.303^{d}$ & 2.07 & 2.75 & 0.17 & 0.049 & 8 \\
\hline I & 13 & $31.24^{\mathrm{a}}$ & 21.27 & 42.29 & 5.22 & 2.33 & 17 & $2.821^{b c}$ & 2.52 & 3.21 & 0.19 & 0.068 & 7 \\
\hline $\mathrm{J}$ & 13 & $38.21^{\mathrm{abc}}$ & 33.78 & 48.18 & 5.56 & 2.33 & 15 & $2.707^{a b c}$ & 2.51 & 2.81 & 0.12 & 0.068 & 4 \\
\hline
\end{tabular}

Key: DSS—data set symbol, N-number of measurements; $E_{\mathrm{vd}}$-dynamic deformation modulus; $\overline{\mathrm{x}}, \mathrm{x}_{\min }$, $\mathrm{x}_{\max }$ - mean, minimum and maximum values; $\mathrm{SD}$ - standard deviation; $\mathrm{z}_{\mathrm{p}}$-coefficient of variation; $\mathrm{s} / \mathrm{v}$-ratio of mean plate settlement to settlement velocity, ${ }^{*}$-DSS marked with the same letters do not differ significantly—Tukey test for different $\mathrm{N}(\alpha=0.05)$.

The development of vegetation succession on the road pavement also has a negative influence on the obtained values of s/v parameter (Table 4, Figure 4), but the observed differences in values are much lower and reach between 3\% (F-E) and 10\% (G-H). These relationships were not statistically confirmed, except for the G-H data sets relationship (Table 4).

It is worth emphasizing that the development of vegetation is accompanied by a significant increase of value variability for both $\mathrm{E}_{\mathrm{vd}}$ as well as $\mathrm{s} / \mathrm{v}$ ratio which is, expressed with coefficient of variation $\mathrm{z}_{\mathrm{p}}$ (Table 4 , Figures 3 and 4 ). 


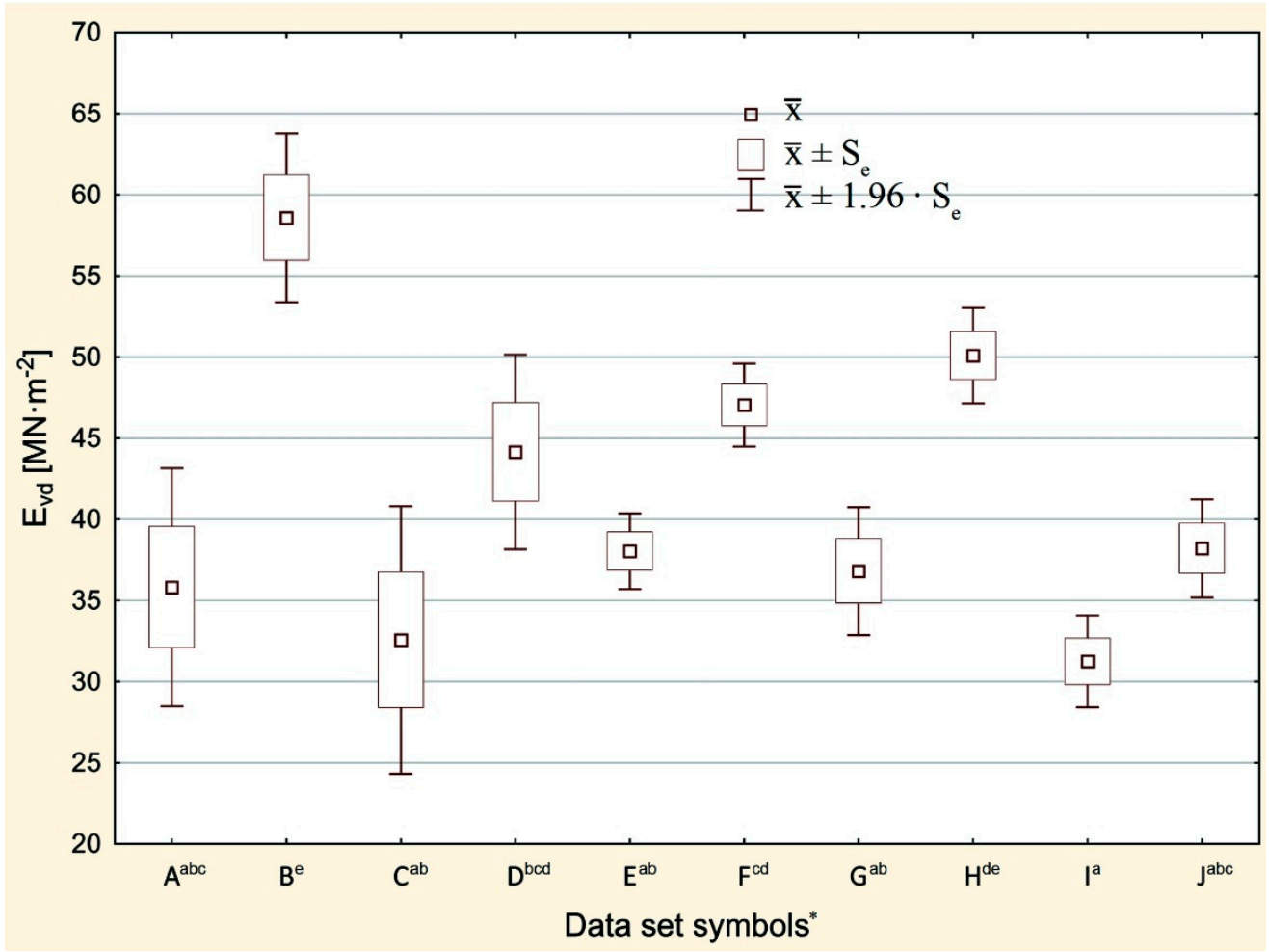

Figure 3. Statistical characteristics of values of dynamic deformation modulus $\left(\mathrm{E}_{\mathrm{vd}}\right)$ by the data set (set symbols according to Table 2). *-DSS marked with the same letters do not differ significantly-Tukey test for different $\mathrm{N}(\alpha=0.05)$.

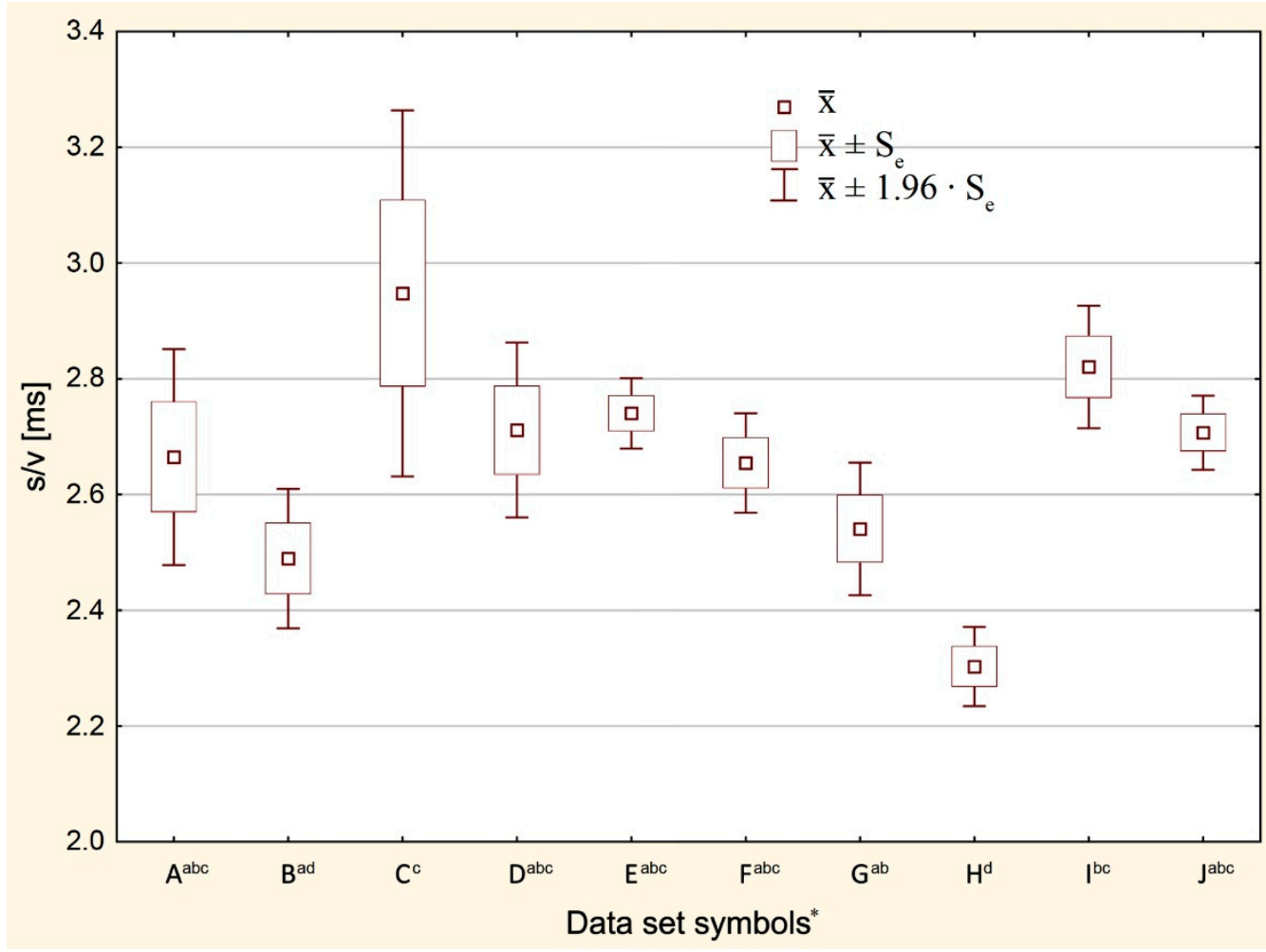

Figure 4. Statistical characteristics of values of $s / v$ values by the data set (set symbols according to Table 2). *-DSS marked with the same letters do not differ significantly-Tukey test for different $\mathrm{N}$ $(\alpha=0.05)$. 


\section{Discussion}

Contrary to the popular opinion about the positive influence of vegetation on the forest road pavement, it is necessary to state that the occurrence of vegetation succession on the analyzed road constructed with unbound aggregate has a negative impact on its bearing capacity parameters.

While converting the dynamic deformation modulus $\left(\mathrm{E}_{\mathrm{vd}}\right)$ into the values of secondary deformation modulus $\left(E_{2}\right)$, which is simply done by doubling the $E_{v d}$ values [40,41], it should be noted that the observed significant decrease of bearing capacity parameters caused by development of vegetation can lead to failing to meet the minimum requirements in this scope i.e., $\mathrm{E}_{2} \geq 100(140) \mathrm{MN} \cdot \mathrm{m}^{-2}$ for road pavement made of unbound crushed stone aggregates [37,42-44].

The values of dynamic deformation modulus, which were measured on the surface without the vegetation on both experimental sections, appeared to differ significantly (Table 4). The reason behind it can be found in the reported problems related to a proper determination of the bearing capacity of the structure reinforced with geosynthetics [45-47]. Nevertheless, the results of the research of both sections in the areas with vegetation suggest that the presence of the geogrid in the road pavement limits the negative impact of the vegetation developing on the pavement (Table 4, Figures 3 and 4). Apparently, the effective wedging of the aggregate by this rigid geosynthetic $[48,49]$ allows at least to slow down the loosening of the aggregate structure by the root systems $[29,30]$ resulting in a decrease in bearing capacity parameters.

The recorded decrease in the value of dynamic modulus of deformation in the third season of testing in comparison to the previously obtained results can be explained by the autumn conditions of the measurements in 2020: the higher humidity of the tested system "pavement structure-road surface" had a negative impact on the obtained parameters of the bearing capacity of the road surface [41,50-53]. However, the recorded decrease in bearing capacity of the road surface may also be affected by the continuous free growth of vegetation root systems, reaching its third growth season, which change the structure of aggregate layer. This is in line with observations made by [22], according to which the dry density of road surface layer decreases with the increase in vegetation cover, which results from successive development of the roots causing an increase in the porosity of surface material.

The observed deterioration of the bearing capacity of the pavement can also be associated with the successive accumulation of organic matter on the pavement after each vegetation season. The stages of plant succession in time are described by [14]. The authors state that immediately after commissioning, the road surface is free of organic pollutants. However, if the strongest seedlings survive after germination, they use remains of successively dying other plants. The assimilation apparatus of plants growing in the vicinity of the roadway also falls down on the pavement. The resulting plant cover shades and cools the surface, initiating at the same time the soil-forming process, including the decomposition of organic compounds and biochemical transformation involving acidic substances secreted by the roots of newly-grown plants [54]. The substances resulting from these processes, including humic acids, migrate deep into the sub-base, affecting the road structure. The organic matter in periods of high moisturization absorbs water, which freezes in winter. As a result, the organic substance penetrating the surface course of the road, alternately increases and decreases its volume, and thus loosens the course structure. The need to remove organic matter from forest roads was indicted by [35], among others. Removing surface organic matter can delay the succession process on roads used occasionally.

The root systems of plants themselves can also cause damage to the surface. Pioneer plant root architecture tends to penetrate the substrate both vertically and horizontally [28]. On the analyzed forest road surfaces, the dominant species was silver birch. The birch has root system of the intensive type, the small adventitious roots are grouped into bundles that penetrate the ground firmly (Figure 5). Similarly, the roots of other pioneer species listed in the inventory results (see Table 3) strongly penetrate the road surface. 


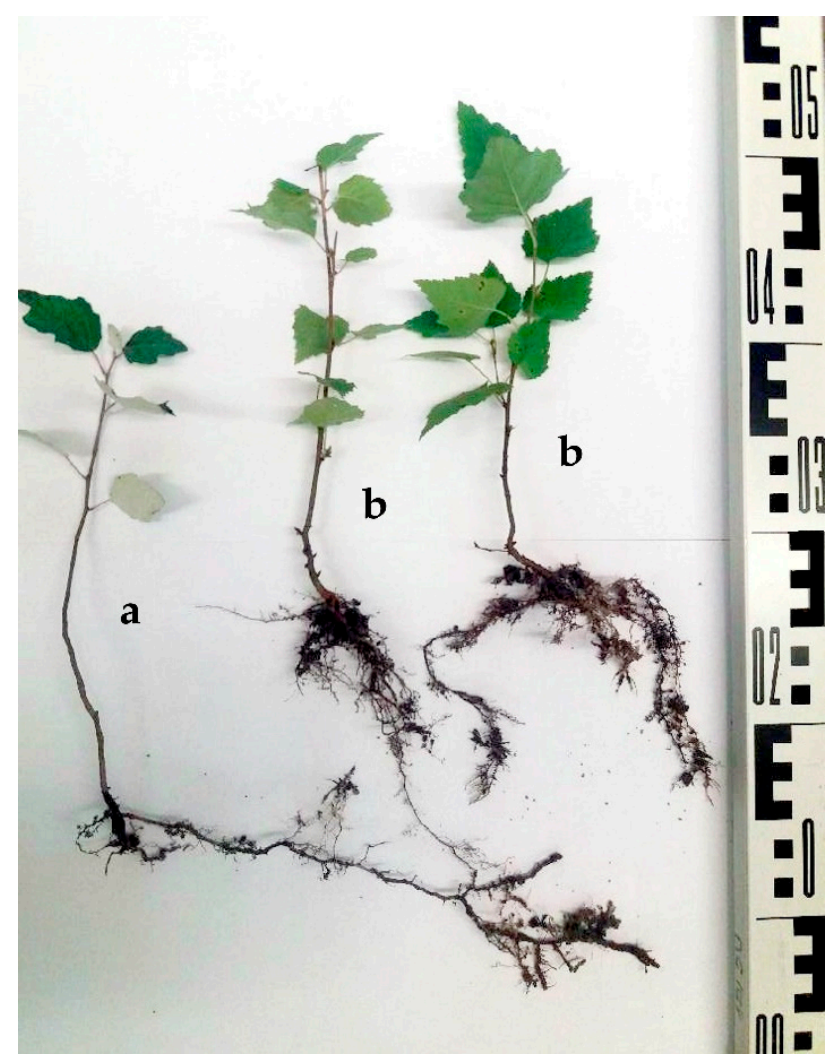

Figure 5. Examples of 2-year-old vegetation specimens growing on experimental road sections: grey poplar (a) and silver birch (b). Overground parts (shoots) and root systems are shown. The average weight of grey poplar was: $2.3 \mathrm{~g}$, and silver birch 3.1; the weight of above-ground and underground parts were: $1.1 \mathrm{~g}$ and $1.2 \mathrm{~g}$ respectively for grey poplar; $2.0 \mathrm{~g}$ and $1.1 \mathrm{~g}$ for silver birch (Photo: A. Czerniak).

\section{Conclusions}

(1) The significant deterioration of bearing capacity parameters of the pavement caused by the developing vegetation succession on the surface indicates that systematic mowing of the surface (including the maneuvering, storage and passing areas) should be regarded as a standard and mandatory practice in order to preserve roads in forests.

(2) Cutting off the vegetation close to the ground does not lead to the significant increase in bearing capacity parameters, which means that the owners/maintenance crew of the road should counteract any vegetation growth, and as a final measure eradicate it as soon as possible.

(3) On the forest roads exploited less intensively, it is recommended to mechanically remove the organic matter that accumulates on the surface. This treatment will delay the growth of vegetation on the surface. Humus removal is easier and cheaper than mechanical removal of plants and safer when using herbicide compounds.

Author Contributions: Conceptualization, A.C.; methodology, A.C. and S.M.G.; validation, S.M.G. and A.C.; formal analysis, A.C., S.M.G. and E.E.K.; investigation, S.M.G. and A.C.; resources, S.M.G., A.C. and E.E.K.; data curation, S.M.G.; writing - original draft preparation, S.M.G. and A.C.; writing-review and editing, A.C., S.M.G. and E.E.K.; visualization, S.M.G.; supervision, A.C.; project administration, E.E.K.; funding acquisition, A.C. All authors have read and agreed to the published version of the manuscript.

Funding: The publication is co-financed within the framework of Ministry of Science and Higher Education programme as "Regional Initiative Excellence" in years 2019-2022, project number 005/RID/2018/19.

Acknowledgments: We would like to thank Karolina Duńska and Rafał Borkowski for their valuable assistance in research logistics and collecting the field data throughout this study.

Conflicts of Interest: The authors declare no conflict of interest. 


\section{References}

1. Trzciński, G.; Czerniak, A.; Grajewski, S. Funkcjonowanie infrastruktury komunikacyjnej obszarów leśnych. Infrastruct. Ecol. Rural Areas 2016, 2, 527-542. [CrossRef]

2. Munro, R. Dealing with Bearing Capacity Problems on Low Volume Roads Constructed on Peat. ROADEX II Project. Scotland. 2004. Available online: http://www.roadex.org/wp-content/uploads/2014/01/2_5-Roadson-Peat_l.pdf (accessed on 8 August 2020).

3. Dzikowski, J.; Szarłowicz, A.; Burzyński, S.; Rajsman, M.; Satoła, J.; Wiązowski, Z. Drogi Leśne. Poradnik Techniczny; DGLP w Warszawie, OR-W LP: Warszawa-Bedon, Poland, 2006; p. 136.

4. Godlewski, D. Nawierzchnie Drogowe; Oficyna Wydaw. PW: Warszawa, Poland, 2011; p. 274. ISBN 978-83-7207-965-7.

5. Trzciński, G.; Kozakiewicz, P.; Selwakowski, R. The technical aspects of using timber in the construction of forest roads. J. Water Land Dev. 2017, 34, 241-247. [CrossRef]

6. Kozakiewicz, P.; Trzciński, G. Wood in the construction of forest roads on poor-bearing road subgrades. Forests 2020, 11, 138. [CrossRef]

7. Ramesh, H.N.; Manoj Krishna, K.V.; Mamatha, H.V. Compaction and strength behavior of lime-coir fiber treated Black Cotton soil. Geomech. Eng. 2010, 2. [CrossRef]

8. Subramani, T.; Udayakumar, D. Experimental study on stabilization of clay soil using coir fiber. IJAIEM 2016, 5, 192-204.

9. Anandhamurugan, A.; Karuppasamy, K.; Jagan, S. Study on the stabilization of soil using coir fibers. JARBEST 2017, 3, 101-110.

10. Muthu Lakshmi, S.; Sasikala, S.; Padmavathi, V.; Priya, S.; Saranya, V. Improvement of local subgrade soil for road construction by the use of coconut coir fiber. IJRET 2018, 5, 2873-2878.

11. Raut, S.R.; Gadhawe, P.S.; Ingole, Y.U. Review on stabilization of soil using coconut coir fibre. IRJET 2020, 7, 1467-1469.

12. Nita, P.; Graczyk, M. Ground and sward airfield pavements. Pr. Inst. Badaw. Dróg Most. 1998, 3-4, 45-62.

13. Carr, W.W. A Handbook for Forest Roadside Erosion Control in British Columbia. Land Management Report No. 4. Province of British Columbia; Ministry of Forests, Information Service Branch: Victoria, BC, Canada, 1980.

14. Forman, R.T.T.; Sperling, D.; Bissonette, J.; Clevenger, A.P.; Cutshall, C.; Dale, V.; Fahrig, L.; France, R.; Goldman, C.; Heanue, K.; et al. Road Ecology: Science and Solutions; Island Press: Washington, DC, USA, 2003.

15. Dyrness, C.T. Grass-legume mixtures for erosion control along forest roads in western Oregon. J. Soil Water Conserv. 1975, 30, 169-173.

16. Grace, J.M. Forest road sideslopes and soil conservation techniques. J. Soil Water Conrewatlon 2000, 65, 96-101.

17. Grace, J.M. Effectiveness of vegetation in erosion control from forest road sideslopes. Transactions of the ASAE. Am. Soc. Agric. Eng. 2002, 45, 681-685. [CrossRef]

18. Arnáez, J.; Larrea, V.; Ortigosa, L. Surface runoff and soil erosion on unpaved forest roads from rainfall simulation tests in northeastern Spain. Catena 2004, 57, 1-14. [CrossRef]

19. Cao, C.; Chen, L.; Gao, W.; Chen, Y.; Yan, M. Impact of planting grass on terrene roads to avoid soil erosion. Landsc. Urban Plan. 2006, 78, 205-216. [CrossRef]

20. Fu, B.; Newham, L.T.H.; Ramos-Scharrón, C.E. A review of surface erosion and sediment delivery models for unsealed roads. Environ. Model. Softw. 2010, 25, 1-14. [CrossRef]

21. Akbarimehr, M.; Naghd, R. Reducing erosion from forest roads and skid trails by management practices. J. For. Sci. 2012, 58, 165-169. [CrossRef]

22. Teramoto, Y.; Shimokawa, E.; Ezaki, T.; Chun, K.-W.; Kim, S.-W. Factors controlling sediment production from a yarding road and its temporal pattern in an abandoned clear-cut plantation forest in the Shirasu (pyroclastic flow deposits) area, Kagoshima Prefecture, Japan. For. Sci. Technol. 2015, 11, 54-60. [CrossRef]

23. Morschel, J.; Fox, D.M.; Bruno, J.-F. Limiting sediment deposition on roadways: Topographic controls on vulnerable roads and cost analysis of planting grass buffer strips. Environ. Sci. Policy 2004, 7, 39-45. [CrossRef]

24. Zemke, J.J. Runoff and soil erosion assessment on forest roads using a small scale rainfall simulator. Hydrology 2016, 3, 25. [CrossRef]

25. Swanson, F.J.; Dyrness, C.T. Impact of clear-cutting and road construction on soil erosion by landslides in the western Cascade Range, Oregon. Geology 1975, 3, 393-396. [CrossRef] 
26. Dolidon, N.; Hofer, T.; Jansky, L.; Sidle, R. Watershed and forest management for landslide risk reduction. In Landslides-Disaster Risk Reduction; Sassa, K., Canuti, P., Eds.; Springer-Verlag: Berlin/Heidelberg, Germany, 2009; pp. 633-649.

27. Rickli, C.; Graf, F. Effects of forests on shallow landslides-case studies in Switzerland. For. Snow Landsc. Res. 2009, 82, 33-44.

28. Lee, J.-T.; Chu, M.-Y.; Lin, Y.-S.; Kung, K.-N.; Lin, W.-C.; Lee, M.-J. Root traits and biomechanical properties of three tropical pioneer tree species for forest restoration in landslide areas. Forests 2020, 11, 179. [CrossRef]

29. Kopinga, J. Aspects of the damage to asphalt road pavings caused by roots. In The Landscape below Ground. Proceedings of an International Workshop on Tree Root Development in Urban Soils; Watson, G., Neely, D., Eds.; International Society of Arboriculture: Champaign, IL, USA, 1994; pp. 165-178.

30. Randrup, T.B.; McPherson, E.G.; Costello, L.R. A review of tree root conflicts with sidewalks, curbs and roads. Urban Ecosyst. 2001, 5, 209-225. [CrossRef]

31. Helliwell, D.R. The extent of tree roots. Arboric. J. 1986, 10, 341-347. [CrossRef]

32. Cutler, D.F. Interactions between tree roots and construction work. Arboric. J. 1993, 17, 47-55. [CrossRef]

33. Kristoffersen, P. Trees in road foundation materials. Arboric. J. 1999, 23, 57-76. [CrossRef]

34. Papierowska, E.; Szatyłowicz, J.; Ruta, M.; Łachacz, A.; Gnatowskia, T.; Stańczyk, T. Water repellency of soils on unpaved roads in coniferous forests. Catena 2020, 195, 104784. [CrossRef]

35. Boston, K.; Leshchinsky, B.; Kemp, E.; Wortman, R. The use of a rotary asphalt broom to groom aggregate forest roads. Croat. J. For. Eng. 2017, 38, 119-126.

36. Leśne, D. Poradnik Techniczny. Dyrekcja Generalna Lasów Państwowych, Warszawa-Bedoń. 2006. Available online: https://bip.lasy.gov.pl/pl/bip/px_dg \{\}rdlp_torun \{\}nadl_torun \{\}drogi_lesne.pdf (accessed on 10 October 2020).

37. Rolla, S. Badania Materiałów i Nawierzchni Drogowych; WKŁ: Warszawa, Poland, 1985.

38. Instrukcja Obstugi Lekkiego Ugięciomierza Dynamicznego ZFG 3000; Maszynopis, Merazet: Poznań, Poland, 2012.

39. EN ISO 10319:2015 Geosynthetics. Wide-width Tensile Test (ISO 10319:2015); International Organization for Standardization, Technical Committee ISO/TC 221 Geosynthetics: Geneva, Switzerland, 2015.

40. Łupieżowiec, M. Wpływ sztywnych geomateracy na odkształcalność podłoża gruntowego pod nawierzchnie drogowe. Czas. Tech. Środowisko 2012, 109, 53-65.

41. Grajewski, S.M. Functionality of Forest Fire Roads in View of Requirements of Modern Fire Engines and Pumper Trucks and Currently Used Forest Firefighting Tactics and Technologies; Rozprawy Naukowe: Uniwersytet Przyrodniczy w Poznaniu: Poznań, Poland, 2019.

42. PN-S-96023:1984 Konstrukcje Drogowe. Podbudowa i Nawierzchnia z Tłucznia Kamiennego; Polski Komitet Normalizacji Miar i Jakości: Warszawa, Poland, 1984.

43. OST D-05.02.01. Nawierzchnia Ttuczniowa; GDDP: Warszawa, Poland, 1998.

44. Kamiński, B. Badania techniczne dróg leśnych. In Nowoczesne Technologie Budowy Dróg, Mostów i Przepustów Leśnych; Jodłowski, K., Czerniak, A., Eds.; Postępy Techniki w Leśnictwie: Warszawa, Poland, 2012; Volume 119, pp. 47-51.

45. Maślakowski, M.; Bartnik, G.; Kowalczyk, S. Wpływ geosyntetyków na dobór metody pomiaru odkształcenia podłoża. Bud. Inżynieria Środowiska 2013, 4, 281-286.

46. Bartnik, G. Zastosowanie Lekkiej Płyty Dynamicznej do Oceny Jakości Zagęszczenia Warstw Kruszywa Łamanego na Podłożu Gruntowym Wzmocnionym Geosyntetykiem; Maszyn. Rozpr. Dokt. Wydział Inżynierii Lądowej, Politechnika Warszawska: Warszawa, Poland, 2015.

47. Bartnik, G.; Sulewska, M.J. Zastosowanie lekkiej płyty dynamicznej do badania gruntów zbrojonych. Inżynieria Morska Geotech. 2015, 3, 280-285.

48. Haas, R.; Wall, J.; Carroll, R.G. Geogrid reinforcement of granular bases in flexible pavements. Transp. Res. Rec. 1988, 1188, 19-27.

49. Kwon, J.; Tutumluer, E. Geogrid base reinforcement with aggregate interlock and modeling of associated stiffness enhancement in mechanistic pavement analysis. Transp. Res. Rec. J. Transp. Res. Board 2009, 2116, 85-95. [CrossRef]

50. Krarup, J. Bearing Capacity and Water. Part 3: Measured Pavement Performance. Danish Road Institute Note, 253; Danish Road Institute. Road Directorate: Roskilde, Denmark, 1995. 
51. Charlier, R.; Hornych, P.; Srsen, M.; Hermansson, A.; Bjarnason, G.; Erlingsson, S.; Pavsic, P. Water influence on bearing capacity and pavement performance: Field observations. In Water in Road Structures; Movement, Drainage and Effects; Dawson, A., Ed.; Springer: Berlin/Heidelberg, Germany, 2009.

52. Laloui, L.; Charlier, R.; Chazallon, C.; Erlingsson, S.; Hornych, P.; Pavsic, P.; Srsen, M. Water influence on mechanical behaviour of pavements: Constitutive modelling. In Water in Road Structures; Movement, Drainage and Effects; Dawson, A., Ed.; Springer: Berlin/Heidelberg, Germany, 2009; pp. 193-216.

53. Grajewski, S.M. Influence of pavement moisture content on the load-bearing capacity of forest road. Infrastruct. Ecol. Rural Areas 2016, 2, 1451-1462.

54. Sofo, A.; Elshafie, H.S.; Camele, I. Structural and functional organization of the root system: A comparative study on five plant species. Plants 2020, 9, 1338. [CrossRef]

Publisher's Note: MDPI stays neutral with regard to jurisdictional claims in published maps and institutional affiliations.

(C) 2020 by the authors. Licensee MDPI, Basel, Switzerland. This article is an open access article distributed under the terms and conditions of the Creative Commons Attribution (CC BY) license (http://creativecommons.org/licenses/by/4.0/). 